\title{
Detailed mechanism and impact of new- onset late right heart failure during LVAD support
}

\author{
Teruhiko Imamura(1)
}

\author{
Abstract \\ Not applicable. \\ Keywords: Hemodynamics, Mechanical circulatory support, Central venous pressure, Continuous flow
}

To the editor,

Left ventricular assist device (LVAD) unloads the left ventricle and increases cardiac output, whereas LVAD might not be beneficial or rather sometimes harmful for the right heart. New-onset late right heart failure is receiving great concern as unsolved comorbidity thus far. Wagner and colleagues demonstrated that preoperative right heart failure enhanced the risk of early right heart failure post-LVAD and persistent late right heart failure, but not the risk of new-onset late right heart failure [1]. Their findings let us hypothesizing different etiology between early and late right heart failures. Several concerns should more enhance the implication of their findings.

Their concept of "new-onset late right heart failure" would be almost similar to "late-onset right ventricular failure" that we proposed in 2014 [2]. I completely agree with them that a new onset late right heart failure would have a unique etiology, which cannot be predicted simply by the existence of preoperative right heart failure. Instead, as we hypothesized, considerable shrinkage of the left ventricle and associated positive remodeling of the right ventricle during LVAD supports might be a mechanism of late right heart failure [2]. Did any patients have preoperative small left ventricle or etiology of hypertrophic cardiomyopathy? How do the authors hypothesize the mechanism of late right heart failure?

Our team recently demonstrated that right heart failure was associated with hemocompatibility-related adverse events [3]. In their study, late right heart failure was associated with higher mortality. Do the authors have data on causes of death in their study? Such data would more clarify the clinical impact of late right heart failure during LVAD supports.

\section{Abbreviations \\ LVAD: Left ventricular assist device}

\section{Acknowledgments}

none.

\section{Author's contributions}

$\mathrm{Tl}$, conceptualization and preparation of the draft. The author(s) read and approved the final manuscript

\section{Funding \\ None.}

Availability of data and materials

No data.

Ethics approval and consent to participate

Not applicable.

\section{Consent for publication \\ Not applicable.}

\section{Competing interests \\ None.}


Received: 1 June 2020 Accepted: 4 September 2020

Published online: 10 September 2020

\section{References}

1. Wagner T, Bernhardt AM, Magnussen C, Reichenspurner H, Blankenberg S, Grahn H. Right heart failure before LVAD implantation predicts right heart failure after LVAD implantation - is it that easy? J Cardiothorac Surg. 2020; 15:113.

2. Imamura T, Kinugawa K, Kato N, Muraoka H, Fujino T, Inaba T, Maki H, Kinoshita O, Hatano M, Kyo S, Ono M. Late-onset right ventricular failure in patients with preoperative small left ventricle after implantation of continuous flow left ventricular assist device. Circ J. 2014;78:625-33.

3. Imamura T, Nitta D, Fujino T, Smith B, Kalantari S, Nguyen A, Narang N, Holzhauser L, Rodgers D, Song T, Ota T, Jeevanandam V, Kim G, Sayer G, Uriel N. Deep Y-descent in right atrial waveforms following left ventricular assist device implantation. J Card Fail. 2020;26:360-7.

\section{Publisher's Note}

Springer Nature remains neutral with regard to jurisdictional claims in published maps and institutional affiliations.

- fast, convenient online submission

- thorough peer review by experienced researchers in your field

- rapid publication on acceptance

- support for research data, including large and complex data types

- gold Open Access which fosters wider collaboration and increased citations

- maximum visibility for your research: over $100 \mathrm{M}$ website views per year

At $\mathrm{BMC}$, research is always in progress. 